\title{
Perilaku Caring menurunkan Kecemasan Pasien Preoperasi
}

\author{
Sulastri $^{1}$, Ade Ira Cahyanti ${ }^{2}$, El Rahmayati ${ }^{3}$ \\ Jurusan Keperawatan, Politeknik Kesehatan Tanjung Karang, Indonesia \\ Email: sulastri@poltekkes-tjk.ac.id
}

\begin{abstract}
Caring Behavior Reduces Anxiety in Preoperative Patients. Invasive actions are closely related to psychological problems, special feelings of anxiety. Uncertain health conditions during and after procedures that can occur during surgery are decided for the patient's recovery. Need special methods from nurses to help patients cope with anxiety, such as caring nurses caring. The purpose of this study is to know the effect of the caring behavior of nurses on preoperative patient's anxiety levels. This research uses a quasi-experimental approach 1 design with a pretestposttest one group design. This study was conducted in June 2018 in the Surgical Inpatient Room RSUD Dr.H Abdul Moeloek Lampung Province. The technique of sampling using nonprobability by purposive sampling, got a sample counted 38 respondents. Bivariate analysis using paired sample t-test. The result showed that the average score of the respondent anxiety index before caring behavior of nurse was 40,50 and the score after caring behavior was 34,63. The difference in the mean score of anxiety index score before and after caring behavior was 5.87 with the pvalue of 0.000 . Based on the conclusion of the research, the writer suggests that the interaction of nurses to the patient is improved and the Standard Operating Procedure of the frequency and duration of the nurse contact to the patient especially the preoperative patient can develop the use of the Caring Dimensions Inventory which covers biological, psychological, social and spiritual aspects.
\end{abstract}

Keywords: Anxiety, Caring, Preoperative

\begin{abstract}
Abstrak: Perilaku Caring Menurunkan Kecemasan Pasien Preoperasi. Tindakan invasive umumnya berkaitan erat dengan masalah psikologis, khususnya perasaan cemas. Ketidakpastian kondisi kesehatan selama dan setelah prosedur yang dapat muncul seiring diputuskannya tindakan operasi untuk kesembuhan pasien. Perlu metode khusus dari perawat untuk membantu pasien mengatasi cemasnya, seperti perilaku caring perawat. Tujuan penelitian mengetahui pengaruh perilaku caring perawat terhadap tingkat kecemasan pasien preoperasi. Penelitian ini menggunakan pendekatan quasi eksperimental design dengan rancangan one grup pretestposttest. Penelitian dimulai dari melakukan pre-test dilanjutkan dengan intervensi selama pasien menjalani perawatan menjelang tindakan operasi selama tiga hari dan dilanjutkan dengan post-test. pengdi Ruang Rawat Inap Bedah RSUD Dr.H Abdul Moeloek Provinsi Lampung. Tehnik sampling menggunakan non-probability secara purposive sampling, sampel didapat sebanyak 38 responden. Analisa bivariat menggunakan uji t dependen. Hasil penelitian diperoleh bahwa ratarata skor indeks kecemasan responden sebelum perilaku perawat adalah 40,50 dan setelah perilaku caring perawat adalah 34,63. Nilai perbedaan rata-rata skor indeks kecemasan sebelum dan sesudah perilaku caring adalah 5,87 dengan nilai p-value 0,000. Berdasarkan kesimpulan hasil penelitian, penulis menyarankan agar interaksi perawat kepada pasien ditingkatkan dan dibuatnya Standar Operasional Prosedur (SOP) frekuensi dan lamanya waktu kontak perawat kepada pasien khususnya pasien preoperasi, melakukan evaluasi terhadap kepuasan pasien terhadap pelayanan keperawatan serta dapat mengembangkan penggunaan Caring Dimensions Inventory (CDI) yang mencakup aspek biologis, psikologis, sosial dan spiritual.
\end{abstract}

Kata kunci: Tingkat kecemasan, Caring, Preoperasi

\section{PENDAHULUAN}

Caring menjadi hal yang utama untuk dilakukan dalam penerapan asuhan keperawatan pada pasien, baik pasien sebagai individu, kelompok, keluarga dan masyarakat. International associationof human caring (2007 dalam Sumartini, 2017), menyatakan ada empat konsep yang perlu perhatikan dalam memberikan asuhan keperawatan, yaitu: keperawatan, manusia, kesehatan, dan lingkungan. Penjelasan dari keempat konsep ini mengingatkan kita bahwasanya empat konsep ini saling berhubungan dan perlu mendapatkan perhatian 
saat perawat memberikan asuhan keperawatan. Keperawatan memberikan informasi tindakan yang dilakukan dalam asuhan keperawatan. Manusia merupakan penerima asuhan keperawatan. Kesehatan menjadi tujuan asuhan keperawatan dan lingkungan merupakan tempat yang perlu kita kondisikan/modifikasi untuk melakukan asuhan keperawatan. Seiring dengan perkembangan ilmu keperawatan ada satu konsep lagi yang juga harus menjadi pelengkap 4 konsep terdahulu, yaitu caring (Shoffner, 2008 dalam Sumartini, 2017).

Caring sudah selayaknya diaplikasikan dalam asuhan keperawatan. Asuhan keperawatan dalam tindakan keperawatan bertujuan untuk memahami hubungan antara kesehatan, penyakit dan kebiasaan manusia. Perawat harus mengerti perbedaan sehat, sakit dan penyakit. Klien dan keluarganya harus berhadapan dengan perubahan sebagai akibat dari sakit dan terapinya. Sakit yang berat, dapat menyebabkan perubahan emosional dan tingkah laku yang besar seperti kegelisahan atau kecemasan, syok, penolakan, kemarahan atau penarikan diri (Potter \& Perry, 2009). Penatalaksanaan dalam asuhan keperawatan dilakukan di sepanjang rentang sehat sampai sakit, baik pada kondisi tindakan non pembedahan dan pembedahan.

Perilaku caring perawat dalam merawat pasien merupakan hal yang menarik untuk diteliti, dan apakah supervisi klinis juga mempunyai pengaruh terhadap perilaku caring perawat dalam merawat pasien mengingat tingkat kebutuhan dari pasien yang semuanya sangat bergantung pada perawat (Rohmatulloh, 2018).

Kecemasan merupakan respon emosional terhadap penilaian yang menggambarkan keadaan khawatir, gelisah, takut dan tidak tentram disertai berbagai situasi kehidupan manapun sebagai gangguan sakit (Nursalam, 2012). Kecemasan bisa muncul sendiri atau bergabung dengan gejala lain yang bersifat fisik dengan berbagai gangguan emosi diantaranya adalah : jari tangan dingin, detak jantung makin cepat, berkeringat dingin, kepala pusing, nafsu makan berkurang, tidur tidak nyenyak, dada sesak. Gejala yang bersifat mental adalah : ketakutan merasa akan ditimpa bahaya, tidak dapat memusatkan perhatian, tidak tenteram, hingga ingin lari dari kenyataan (Ramaiah, 2003; Sundari, 2009).

Sebagian besar pasien yang masuk rumah sakit untuk menjalani operasi elektif akan mengalami kecemasan (Perdana, 2014). Menurut Potter \& Perry dalam Haqiki (2013) pasien yang menghadapi pembedahan akan mengalami ketakutan atau kecemasan diantaranya karena takut nyeri, takut terjadi perubahan fisik, dan takut operasi gagal. Kecemasan dapat menimbulkan perubahan scara fisik maupu psikologis yang akhirnya mengaktifkan saraf otonom simpatis sehingga meningkatkan denyut jantung, tekanan darah, frekuensi nafas, dan secara umum mengurangi tingkat energi pasien dan akhirnya akan berdampak pada proses pembedahan (Muttaqin, 2009). Dampak yang dapat ditimbulkan ialah penundaan atau pembatalan operasi. Menurut Hong (2003 dalam Perdana, 2014) masalah yang sering dihubungkan dengan kecemasan preoperasi diantaranya ialah nyeri pasca bedah yang lebih tinggi, kejadian mual muntah pasca bedah, memperpanjang masa pemulihan dan perawatan rumah sakit. Penelitian Inayati (2017) disimpulkan bahwa terdapat hubungan secara signifikan antara tingkat kecemasan pada pasien preoperasi dengan tekanan darah pada pasien preoperasi elektif di RSUD Jend. Ahmad Yani Kota Metro dengan nilai $p$-value 0,023 .

Menurut Carpenito (2002) bahwa 90\% pasien preoperasi berpotensi mengalami kecemasan. Kecemasan yang dialami pasien preoperasi mempunyai bermacam-macam alasan diantaranya cemas menghadapi ruang operasi dan peralatan operasi, cemas terjadinya perubahan fisik (body image) yang berupa cacat anggota tubuh, cemas dan takut di bius, cemas bila operasi gagal, ataupun cemas masalah biaya yang membengkak (Savitri, 2008).

Berdasarkan data World Health Organization (WHO) pada tahun 2007, Amerika Serikat menganalisis data dari 35.539 klien bedah yang dirawat di unit perawatan intensif Oktober 2003 sampai September 2006, sebanyak 8.922 pasien $(25,1 \%)$ mengalami kondisi kejiwaan, dan 2.473 pasien $(7 \%)$ mengalami kecemasan. Pada tahun 2007 sebanyak 401 RSU di Indonesia, melaksanakan tindakan operasi sebanyak 642.632 pasien, yang dirinci menurut tingkat kelas rumah sakit tipe A, B, C, dan D, data tersebut diklasifikasikan berdasarkan jenis operasi.

Menurut penelitian Rahmayati (2016) disimpulkan ada perbedaan pengaruh terapi psiko-religius dan terapi musik klasik terhadap kecemasan pasien preoperasi di RSUDAM Provinsi Lampung tahun 2016 (p-value 0.030) dengan penggunaan skor ZSRS pada pasien yang diterapi dengan terapi psiko-religius sebesar 2, 250. Hasil survei awal yang dilakukan peneliti di ruang Ruang Rawat Inap Bedah Wanita RSUD Dr. H Abdul Moeloek Provinsi Lampung pada tanggal 10-25 Februari 2018 didapatkan 20 pasien preoperasi menunjukkan respon 
kecemasan. 7 orang (35\%) menunjukkan respon kognitif, 6 orang $(30 \%)$ menunjukkan respon afektif, 4 orang (20\%) menunjukkan respon fisiologis dan 3 orang (15\%) menunjukkan respon perilaku. Dari rata-rata jumlah pasien yang menjalani pembedahan setiap bulannya, didapatkan data bahwa dua pasien mengalami penundaan operasi beberapa saat dan tiga pasien mengalami pembatalan operasi di hari yang telah ditentukan disebabkan oleh peningkatan tekanan darah.

Menurut Smeltzer and Bare (2000 dalam Arbani, 2015), penatalaksanaan kecemasan ialah psikoterapi, farmakoterapi, dan pendekatan suportif yang berkaitan dengan perilaku caring perawat. Caring bukan merupakan perlakuan khusus yang diberikan kepada klien, namun caring mewakili semua faktor yang digunakan perawat untuk memberikan pelayanan kepada klien (Potter \& Perry, 2009).

Caring dapat meningkatkan aktualisasi diri, mendukung pertumbuhan individu, menjaga martabat dan nilai manusia, membantu penyembuhan diri, dan mengurangi distress (Kozier B. 2010). Menurut Depkes RI (1983, dalam Kurniawan, 2008), dengan adanya sikap perawat yang hangat, penuh perhatian dan tegas, pasien akan mendapat pengalaman emosional yang baik. Adanya perilaku caring yang cukup dari perawat akan meminimalkan kejadian kecemasan.

Caring merupakan sentral praktik keperawatan, tetapi hal ini lebih penting dalam kekacauan lingkungan pelayanan kesehatan saat ini.Kebutuhan, tekanan, dan batas waktu dalam lingkungan pelayanan kesehatan berada dalam ruang kecil praktik caring yang membuat perawat dan profesi kesehatan lainnya menjadi dingin dan tidak peduli terhadap kebutuhan klien (Potter \& Perry, 2009). Penelitian Prabowo (2014) tentang perilaku caring di RSU Bondowoso menunjukkan bahwa 50\% perawat berperilaku kurang caring. Selanjutnya, penelitian yang dilakukan oleh Prihandhani (2015) tentang perilaku caring di Rumah Sakit Umum Ganesha Gianyar mendapatkan hasil 43,7\% perawat berperilaku kurang caring.

Kozier, Erb, Berman, dan Snyder (2010) menyatakan bahwa caring merupakan intisari keperawatan dan karakteristik yang dominan, khusus, serta tidak terpisahkan dalam keperawatan. Sehingga penting bagi seorang perawat dalam meningkatkan perilaku caringnya.

Perilaku caring tergambar pada Caring Dimension Inventory (CDI). Di Indonesia, studi tentang perilaku caring mulai dikembangkan salah satunya oleh Muhlisin (2008), namun belum ada kesepakatan tentang standar Caring Dimension Inventory yang dapat digunakan perawat, sehingga saat ini persepsi perawat tentang perilaku caring tidaklah sama.

Menurut Potter \& Perry (2009) sikap caring salah satunya ialah kehadiran. Hasil pengamatan peneliti terhadap beberapa perawat yang bertugas didapatkan bahwa perawatan yang dilakukan hanya didominasi oleh penyakit fisik. Hal ini diperkuat dengan kurangnya intensitas kehadiran perawat dalam proses keperawatannya dan kurangnya dukungan psikologis untuk pasien selama preoperasi. Selain itu, saat berinteraksi dengan pasien, perawat belum menunjukkan sikap caring seperti kehadiran, sentuhan, mendengarkan, memahami klien. Oleh karena itu, peneliti tertarik untuk melakukan penelitian tentang pengaruh perilaku caring terhadap tingkat kecemasan pasien preoperasi di Ruang Rawat Inap Bedah RSUD Dr. H Abdul Moeloek Provinsi Lampung.

\section{METODE}

Penelitian ini menggunakan pendekatan quasi eksperimental design dengan rancangan one grup pre-test post-test. Penelitian ini dilakukan pada di ruang rawat yaitu ruang rawat inap bedah wanita (mawar) dan ruang rawat inap bedah pria (kutilang) RSUD Dr. H Abdul Moeloek Provinsi Lampung. Populasi dalam penelitian ini adalah seluruh pasien yang dirawat di Ruang Rawat Inap Bedah dan akan menjalani pembedahan elektif yang sesuai dengan kriteria inklusi. Sample berjumlah 38 responden yang diambil dengan tehnik probability sampling secara purposive sampling. Analisa bivariat menggunakan uji t berpasangan (paired sample $t$ test). Instrumen pengumpulan data menggunakan kuisioner Zung Self Anxiety Rating Scale dan panduan perilaku caring perawat.

Penelitian dilakukan dengan mengumpulkan data kecemasan pada pasien memberikan intervensi berupa perilaku caring dalam asuhan keperawatan.

Penelitian ini telah mendapat keterangan kelaikan etik (ethical clearance) dari Komisi Etik Penelitian Kesehatan Politeknik Kesehatan Tanjung Karang Nomor: 128/EC/KEPTJK/VI/2018. 


\section{HASIL}

\section{Karakteristik Responden}

Tabel 1. Gambaran Responden

\begin{tabular}{lrr}
\hline \multicolumn{1}{c}{ Variabel } & n & \% \\
\hline Jenis Kelamin & & \\
Perempuan & 19 & 50 \\
Laki Laki & 19 & 50 \\
\hline Usia & & \\
18-25 tahun (dewasa muda) & 4 & 10,5 \\
26-35 tahun (dewasa awal) & 7 & 18,4 \\
36-45 tahun (dewasa akhir) & 13 & 34,2 \\
46-55 tahun (lansia awal) & 10 & 26,3 \\
56-65 tahun (lansia akhir) & 4 & 10,5 \\
\hline Pendidikan & & \\
SD & 15 & 39,5 \\
SMP & 10 & 26,3 \\
SMA & 13 & 34,2 \\
\hline Pengalaman operasi & & \\
Pernah & 8 & 21,1 \\
Tidak pernah & 30 & 78,9 \\
\hline Tingkat kecemasan & & \\
Ringan & 23 & 60,5 \\
Sedang & 12 & 31,6 \\
Berat & 3 & 7,9 \\
\hline
\end{tabular}

\section{Perbedaan rata-rata skor Zung Self Anxiety Rating Scale}

Tabel 2. Perbedaan rata-rata skor Zung Self Anxiety Rating Scale

\begin{tabular}{|c|c|c|c|c|}
\hline $\begin{array}{c}\text { Nilai } \\
\text { ZSARS }\end{array}$ & Mean & SD & p-value & $\mathbf{n}$ \\
\hline Sebelum & 40,50 & 9,417 & 0,000 & 38 \\
\hline Sesudah & 34,63 & 8,613 & & \\
\hline
\end{tabular}

\section{PEMBAHASAN}

Hasil penelitian ini diperoleh data rata-rata skor kecemasan responden sebelum mendapatkan perilaku caring perawat ialah 40,50 dengan standar deviasi (SD) 9,417 dan skor kecemasan terendah adalah 24 (cemas ringan) dan skor kecemasan tertinggi adalah 60 (cemas berat), dimana nilai 40,50 masuk dalam kategori cemas ringan (20-44). Sedangkan rata-rata skor kecemasan responden sesudah mendapatkan perilaku caring perawat ialah 34,63 dengan standar deviasi (SD) 8,613 dan skor kecemasan terendah adalah 20 (cemas ringan) dan skor kecemasan tertinggi adalah 54 (cemas sedang). Secara kuantitatif, penelitian ini bermakna karena menunjukkan penurunan skor kecemasan, dimana angka 34,63 termasuk dalam kategori cemas ringan (20-44).

Berdasarkan hasil penelitian, didapatkan data 13 dari 38 responden berusia 36-45 tahun, dengan kata lain responden yang mengalami kecemasan terbanyak berkisar antara usia 36-45 tahun (dewasa akhir). Menurut Kaplan dan Sadock (1997, dalam Lutfa, 2008) mengatakan bahwa gangguan kecemasan dapat terjadi pada semua usia, lebih sering terjadi pada usia dewasa. Menurut Pieter dan Lubis (2010) dalam Putri (2014), perubahan psikologis pada masa dewasa akhir adalah instabilitas emosi. Pada masa dewasa akhir, muncul berbagai sindrom menjelang menopause salah satunya adalah sindrom perubahan emosi. Sindrom ini menyebabkan seseorang cepat marah dan suka mengkritik. Perubahan psikologis ini akan berdampak pada terganggunya keseimbangan emosi, seperti cemas, stres dan depresi. Hal ini diperkuat oleh penelitian

Gambaran responden berdasarkan tingkat pendidikan didapatkan data bahwa 39,5\% responden (15 responden) yang berpendidikan SD mengalami kecemasan. Menurut Jatman (2000) dalam Lutfa (2008) menyatakan bahwa tingkat pendidikan yang cukup akan lebih mudah dalam mengidentifikasi stressor dalam diri sendiri dan luar dirinya. Tingkat pendidikan juga mempengaruhi kesadaran dan pemahaman terhadap stimulus. Menurut Notoatmojo (2010) pendidikan pada umumnya berguna dalam merubah pola pikir, pola bertingkah laku, dan pola pengambilan keputusan. Kondisi ini menunjukan respon cemas cenderung pada responden berpendidikan rendah, hal ini terjadi karena rendahnya pemahaman sehingga membentuk persepsi yang menakutkan dalam merespon kejadian. Tingkat pendidikan yang rendah pada seseorang akan menyebabkan orang tersebut mengalami kecemasan dibanding mereka yang mempunyai status pendidikan tinggi (Kaplan dan Sadock, 1997 dalam Lutfa, 2008).

Jenis kelamin responden dalam penelitian ini memiliki proporsi yang sama yaitu perempuan $50 \%$ dan laki-laki 50\%. Namun responden perempuan memiliki skor kecemasan yang lebih tinggi dari responden laki-laki. Menurut Kaplan dan Shadock (2010) wanita lebih sering mengalami kecemasan dari pada pria. Wanita memiliki tingkat kecemasan yang tinggi dibandingkan pria. Hal ini dikarenakan bahwa wanita lebih peka dengan emosinya, yang pada akhirnya mempengaruhi perasaan cemasnya. Dalam penelitian ini menunjukkan adanya hubungan yang signifikan antara jenis kelamin dengan tingkat kecemasan pasien dengan $p$-value $0,04<\alpha(0,05)$

Gambaran responden terhadap pengalaman operasi sebagian besar ialah tidak pernah menjalani operasi sebelumnya $(78,9 \%)$. Menurut Kaplan dan Sadock (1997) dalam Lutfa (2008) mengatakan bahwa pengalaman awal pasien 
dalam pengobatan merupakan pengalamanpengalaman yang sangat berharga yang terjadi pada individu terutama untuk masa-masa yang akan datang. Apabila seseorang belum memiliki pengalaman operasi sebelumnya, maka cenderung mempengaruhi peningkatan kecemasan menghadapi operasi. Dalam penelitian ini terdapat hubungan yang signifikan antara pengalaman operasi sebelumnya dengan tingkat kecemasan responden dengan $p$-value $0,037<\alpha \quad(0,05)$. Dimana berdasarkan hasil analisis penelitian diketahui bahwa sebagian besar kecemasan pasien preoperasi dalam kategori kecemasan ringan yaitu sebanyak 23 responden $(60,5 \%)$ dan persentase terkecil dengan tingkat kecemasan berat 3 responden $(7,9 \%)$.

Faktor-faktor yang mempengaruhi kecemasan dalam penelitian ini ialah jenis kelamin dengan $p$-value $0,041<\alpha(0,05)$ dan pengalaman operasi sebelumnya dengan $p$-value $0,037<\alpha(0,05)$.

Hasil analisis bivariat dalam penelitian ini menunjukkan adanya pengaruh perilaku caring perawat terhadap kecemasan pasien preoperasi dengan $p$-value $0,000<\alpha(0,05)$. Hasil uji statistik didapatkan data bahwa rata-rata skor indeks kecemasan responden sebelum perilaku caring perawat adalah 40,50 dan setelah perilaku caring perawat adalah 34,63 . Nilai perbedaan rata-rata skor indeks kecemasan sebelum dan sesudah perilaku caring adalah 5,87.

Menurut Potter \& Perry dalam Haqiki (2013) pasien yang menghadapi pembedahan akan mengalami ketakutan atau kecemasan diantaranya karena takut nyeri, takut terjadi perubahan fisik, dan takut operasi gagal. Sakit yang berat, dapat menyebabkan perubahan emosional dan tingkah laku yang besar seperti kegelisahan atau kecemasan, syok, penolakan, kemarahan atau penarikan diri. Menurut Kusumawati (2010) tingkat kecemasan bermula dari kecemasan ringan, sedang, berat dan panik. Dengan adanya sikap perawat yang hangat, penuh perhatian dan tegas, pasien akan mendapat pengalaman emosional yang baik. Adanya perilaku caring yang cukup dari perawat akan meminimalkan kejadian kecemasan (Depkes RI, 1983 dalam Kurniawan, 2008).

Asumsi dasar sciens of caring Jean Watson juga melibatkan lingkungan caring (Watson, 2007 dalam Muhlisin, 2008). Seseorang yang mengalami kecemasan akan membutuhkan rasa aman. Rasa aman klien yang mengalami kecemasan timbul dengan kehadiran perawat yang tenang. Mengungkapkan perasaan dalam lingkungan yang tidak mengancam dapat membantu klien menghadapi masalah yang belum terselesaikan (Townsend, 2010). Berpakaian rapih ketika bekerja dengan klien (CDI 6), duduk dengan klien (CDI 7), bersikap manis dengan klien (CDI 11), mendengarkan klien (CDI 13), dan bersikap gembira dengan klien (CDI 24) merupakan salah satu hal yang dapat mendukung lingkungan caring.

Salah satu sikap caring perawat menurut Potter dan Perry (2009) yaitu kehadiran. Kehadiran individu terpercaya memberi klien rasa aman serta jaminan keselamatan bagi individu yang mengalami kecemasan (Townsend, 2010). Menjelaskan prosedur klinik (CDI 5), bersikap kompeten dalam prosedur klinik (CDI 7), melibatkan klien dalam perawatan (CDI 21) dapat membangun kepercayaan pasien kepada perawatnya. Membantu klien dalam ADL (CDI 1), Memberikan privacy kepada klien (CDI 23) dapat memberikan rasa aman bagi pasien. Hal ini juga berkaitan dengan salah satu asumsi dasar sciens of caring yang mengatakan bahwa caring dapat didemonstrasikan dan dipraktekkan dengan efektif hanya secara transpersonal (Watson, J \& Robert B. 2012).

Seseorang yang mengalami kecemasan akan mengalami penyempitan lapang persepsi (Kusumawati, 2010). Salah satu carative factors yaitu meningkatkan hubungan interpersonal "teaching-learning" (Alligood, 2010). Hal ini berkaitan dengan aplikasi CDI 17 (memberikan informasi kepada pasien), dan CDI 4 (memberikan pengetahuan kepada pasien sebagai individu). Hal ini berkaitan dengan penelitian yang dilakukan Sulistiyanto (2009) disimpulkan bahwa ada hubungan antara persepsi pasien tentang perilaku caring perawat dengan kecemasan pasien kemoterapi pada kanker payudara di RSUD Dr. Moewardi Surakarta dengan nilai $p$-value $=0,010$.

Hasil penelitian ini didapatkan data bahwa skor indeks kecemasan responden sebelum perilaku caring perawat adalah 40,50. Skor ini mendekati kecemasan sedang (skor 45-59). Perilaku caring perawat dalam penelitian ini dapat mengurangi kecemasan sehingga dapat meminimalkan resiko pembatalan operasi dan penjadwalan ulang sampai keadaan psikologis pasien menjadi lebih baik. Respon kecemasan dapat berupa perubahan scara fisik seperti palpitasi, tekanan darah meningkat, nafas cepat, sesak nafas, tekanan pada dada, nafas dangkal dan rasa ingin pingsan (W.Stuart, 2006). Hal ini juga berkaitan dengan hasil penelitian Inayati (2017) yang disimpulkan bahwa terdapat hubungan secara signifikan antara tingkat kecemasan pada pasien praoperasi dengan 
tekanan darah pada pasien praoperasi elektif di RSUD Jend. Ahmad Yani Kota Metro dengan nilai $p$-value 0,023 .

Manusia merupakan makhluk holistik yang terdiri dari unsur biologis, psikologis, sosial dan spiritual. Di Indonesia, studi tentang perilaku caring sudah mulai dikembangkan seperti CDI25 items yang digunakan didalam penelitian ini didesain oleh Watson dan Lea (1997 yang dikembangkan oleh Muhlisin (2008). Item ini berkaitan dengan aspek biologis dan psikologis pasien. Saat ini studi tentang Caring Dimensions Inventory (CDI)yang berkaitan dengan aspek spiritual telah dikembangkan oleh Alhadidi (2016) berjumlah 29 item (CDI-29) dan yang berkaitan dengan aspek psikososial telah dikembangkan oleh Watson, Deary dan Hoogbruin (2001) berjumlah 35 item (CDI-35).

Perawat yang berperilaku caring dalam penelitian ini mengaplikasikan Caring Dimensions Invetory sesuai dengan kebutuhan pasien preoperasi. Menurut peneliti, perilaku caring dapat dipelajari dan dilakukan oleh semua perawat dan melekat pada setiap bentuk pelayanan asuhan keperawatan. Pasien preoperasi membutuhkan dukungan secara emosional dalam keadaan fisik yang lemah. Rasa empati perawat yang tertuang dalam perilaku caring memberikan rasa tenang dan nyaman untuk pasien. Sehingga kehadiran perawat untuk pasien juga dapat mengurangi tingkat ketergantungan pasien kepada keluarganya serta mengurangi jumlah keluarga yang terlalu ramai berada bersama pasien selama menjalani perawatan di rumah sakit.

Caring merupakan salah satu tindakan keperawatan yang dilakukan setiapkali berinteraksi dengan pasien. Caring dapat diekpresikan dengan perilakuyang tulus, ikhlas, peduli dengan masalah keperawatan yang dihadapi oleh pasien. Pemberian pelayanan keperawatan, perlu memperhatikan tiga aspek yakni care, cure, dan core. Proporsi pelayanan yang diberikan sebanyak tiga perempatnya adalah caring (tindakan yang berfokus pada kenyamanan dan kepuasan bagi klien selama dirawat), sedangkan seperempatnya adalah curing (tindakan pengobatan yang diberikan dalam proses penyembuhan (Watson 2011 \& Lydia, 2011 dalam Manurung \& Hutasoid, 2013).

Hasil penelitian Ardiana A, Sahar J, dan Gayatri D (2010), membuktikan bahwa perilaku caring dapat ditunjukkan dengan kemampuan memahami dan mendukung emosi orang lain, kemampuan perawat menerima perasaan klien sehingga akan terbentuk hubungan saling percaya. Hasil analisis dari 92 perawat pelaksana dan 92 klien yang terlibat, dikatahui persepsi klien sebanyak $54 \%$ perawat berperilaku caring dan $59,8 \%$ perawat memiliki dimensi memahami dan mendukung emosi orang lain. Terdapat hubungan yang signifikan antara dimensi memahami dan mendukung emosi orang lain dengan perilaku caring perawat. Perawat dengan dimensi memahami dan mendukung emosi orang lain yang tinggi berpeluang 2,567 kali lebih caring.

Watson (1988 dalam Cossette, et al., 2006) telah mendeskripsikan caring sebagai cara hidup, bukan cara melakukannya. Setiap upaya untuk mengukur perilaku caring hanya dapat sulit diukur secara langsung, tetapi dapat terlihat pada respons pasien setelah dirawat. Skala yang dikembangkan untuk menilai caring disebut caring nurse-patien interactions (CNPI-Long Scale). Skala ini digunakan untuk menilai sikap dan perilaku yang terkait dengan 10 faktor karatif Watson. Dua alasan menggunakan skala ini adalah untuk meringkas skala asli menjadi versi yang lebih singkat (CNPI-Short Scale). Skala yang diperpendek ini didasarkan pada tiga domain peduli priori yang disintesis dari 10 faktor karatif asli (Cossette, et al., 2006).

\section{SIMPULAN}

Berdasarkan hasil penelitian dapat disimpulkan bahwa perilaku caring perawat berpengaruh terhadap tingkat kecemasan pasien preoperasi. Namun disarankan tenaga keperawatan untuk tetap dapat meningkatkan interaksi dan empati kepada pasien khususnya pasien preoperasi sebagai bentuk upaya meningkatkan mutu pelayanan keperawatan. Pelayananan kesehatan khususnya pasien yang menjalani rawat inap diharapkan dapat membuat Standar Operasional Prosedur (SOP) tentang frekuensi dan lamanya waktu kontak perawat kepada pasien khususnya pasien preoperasi dengan mengaplikasikan Caring berdasarkan Caring Dimensions Inventory (CDI) yang mencangkup aspek biologis, psikologis, sosial dan spiritual, serta melakukan evaluasi terhadap kepuasan pasien terhadap pelayanan keperawatan. 


\section{DAFTAR PUSTAKA}

Alligood, M.R. \& Tomey, A.M. (2010). Nursing theorists and their work. seven. United States of America: Elsevier

Arbani, F. A. (2015). Hubungan Komunikasi Terapeutik Dengan Tingkat Kecemasan Pasien Pre Operasi di RS PKU Muhammadiyah Sukoharjo. [Skripsi]. Surakarta: Stikes Kusuma Husada.

Ardiana, A., Sahar, J., \& Gayatri, D. (2010). Dimensi Kecerdasan Emosional: Memahami dan Mendukung Orang Lain Terhadap Perilaku Caring Perawat Pelaksana Menurut Persepsi Klien. Jurnal Keperawatan Indonesia, 13(3), 133-138.

Carpenito. (2002). Buku Saku Diagnosa Keperawatan. Edisi 8. Jakarta: EGC.

Cossette, S., Cote, J. K., Pepin, J., Ricard, N., \& D'Aoust, L. X. (2006). A dimensional structure of nurse-patient interactions from a caring perspective: refinement of the Caring Nurse-Patient Interaction Scale (CNPI-Short Scale). Journal of Advanced Nursing, 55(2), 198-214.

Depkes RI. (2007). Profil Kesehatan Indonesia. Jakarta: Depkes RI.

Haqiki, S. A. N. (2013). Hubungan Dukungan Keluarga Dengan Tingkat Kecemasan Pasien Pre Operasi Di Ruangan Bedah Baji Kamase 1 Dan 2 RSUD Labuang Baji Makassar. [Skripsi]. Makassar: Universitas Islam Negeri Alauddin.

Inayati, A. (2017). Hubungan Tingkat Kecemasan Dengan Peningkatan Tekanan Darah Pada Pasien Praoperasi Elektif di Ruang Bedah. Jurnal Wacana Kesehatan, l(1), 163-168.

http://jurnal.akperdharmawacana.ac.id/inde x.php/wacana/article/view/43/18

Kaplan, HI, Sadock, BJ \&Grabb, JA. (2010). Kaplan-Sadock Sinopsis Psikiatri Ilmu Pengetahuan Prilaku Psikiatri Klinis. Tangerang: Bina Rupa Aksara.

Kozier, B. (2010). Buku Ajar Fundamental Keperawatan : Konsep, Proses \& Praktik. Jakarta: EGC.

Kozier, B., Erb, G., Berman, A., \& Snyder, S. J. (2010). Buku Ajar Fundamental Keperawatan: Konsep, Proses, dan Praktik. Jakarta: EGC.

Kurniawan, A. (2008). Faktor-faktor yang berhubungan dengan tingkat kecemasan orang tua terkait hospitalisasi anak usia toddler di BRSD RAA Soewonso Pati. FIKkeS, 1(2).
Kusumawati, F. d. (2010). Buku Ajar Keperawatan Jiwa. Jakarta: Salmeba Medika.

Manurung, Suryani \&Hutasoid, Mey LysCeryah. (2013). Persepsi Pasien terhadap Perilaku Caring Perawat di Ruang Rawat Inap Rumah Sakit. Jurnal Kesehatan Masyarakat Nasional, Vol. 8 no. 3.

Muhlisin, A. (2008). Aplikasi Model Konseptual Caring Dari Jean Watson. Berita Ilmu Keperawatan, 1(3), 147-150. http://journals.usm.ac.id/index.php/BIK/art icle/vew/3752

Muttaqin, A. d. (2009). Asuhan Keperawatan Perioperatif. Jakarta: Salemba Medika.

Nursalam. 2012. Manajemen Keperawatan. Jakarta : Salemba Medika.

Notoatmojo, S. (2010). Metodologi Penelitian Kesehatan. Jakarta: Rineka Cipta.

Perdana, A., Firdaus, M. F., \& Kapuangan, C. K. (2016). Uji Validasi Konstruksi dan Reliabilitas Instrumen the Amsterdam preoperative anxiety and information scale (APAIS) Versi Indonesia. Maj Anest Dan Crit Care, 33, 279-86.

Potter \& Perry. (2009). Fundamental Keperawatan Edisi 7 Buku 1. Jakarta: Salemba Medika.

Prabowo, B. S. (2014). Hubungan Tingkat Kognitif Perawat tentang Caring dengan Aplikasi Praktek Caring di Ruang Rawat Inap RSU dr.HKoesnadi Bondowoso. EJurnal Pustaka Kesehatan, 150. http://repository.unej.ac.id/handle/1234567 89/57327.

Prihandhani, I. G. A. S. (2015). Hubungan Faktor Individu dan Budaya Organisasi dengan Perilaku Caring Perawat Pelaksana di Ruang Rawat Inap Rumah Sakit Umum Ganesha Gianyar. Public Health and Preventive Medicine Archive.

Putri, Devi Setya. (2014). Pengaruh Terapi Humor Terhadap Penurunan Kecemasan Pada Pasien Preoperasi Dengan General Anestesi di RS Tolerejo Semarang. Jurnal Ilmu Keperawatan dan Kebidanan. http://ejournal.stikestolerejo.ac.id.

Rahmayati, E., \& Handayani, R. (2016). Perbedaan Pengaruh Terapi Psikoreligius dengan Terapi Musik Klasik terhadap Kecemasan Pasien Pre Operatif di RSUD dr. H. Abdul Moeloek Provinsi Lampung. Jurnal Kesehatan, 191-198. https://www.poltekkestjk.ac.id/ejurnal/inde x.php/JK/article/view/472. 
Rohmatulloh, R., \& Haryani, A. (2018). Hubungan Supervisi Keperawatan dengan Perilaku Caring Perawat dalam Merawat Pasien Kritis. Faletehan Health Journal, 5(3), 129-134.

Ramaiah, S. (2003). Kecemasan, bagaimana mengatasi penyebabnya. Yayasan Obor Indonesia.

Savitri. (2008). Kecemasan. Jakarta: Pustaka Popular Obor.

Sumartini, Tutik. (2017). Hubungan perilaku caring perawat dengan kepuasan pasien JKN di instalasi rawat inap kelas III RSUD Pandan Arang Boyolali. [Skripsi]. Surakarta: Stikes Kusuma Husada. digilib.stikeskusumahusada.ac.id (diakses 12 September 2018).

Sundari, S. (2009). Kesehatan mental dalam kehidupan. Jakarta: Rineka Cipta.
Townsend, MC. (2010). Diagnosis Keperawatan Psikiatri Rencana Asuhan \& Medikasi Psikotropik. Jakarta: EGC.

Lutfa, U., \& Maliya, A. (2008). Faktor-faktor yang mempengaruhi kecemasan pasien dalam tindakan kemoterapi di Rumah Sakit Dr. Moewardi Surakarta. Berita Ilmu Keperawata, Vol. 1 No. 4.

W. Stuart, G. (2006). Buku Saku Keperawatan Jiwa Edisi 5. Jakarta: EGC.

Watson, J., \& Browning, R. (2012). Viewpoint: Caring science meets heart science: A guide to authentic caring practice. American Nurse Today, 7(8), 4-8.

World Health Organization (WHO). (2015). World Health Statistics 2015. World Health Organization. 